\title{
A Study of College Students' Civil Servants Fever Based on Chinese and Western Values
}

\author{
Qian Zhang1, Xiufeng Tian² \\ ${ }^{1}$ Foreign Language Department, Baoding University, Baoding, China \\ ${ }^{2}$ Foreign Language Department, Hebei Finance University, Baoding, China \\ Email: zq757602@163.com
}

Received 20 April 2014; revised 24 May 2014; accepted 11 June 2014

Copyright (C) 2014 by authors and Scientific Research Publishing Inc.

This work is licensed under the Creative Commons Attribution International License (CC BY). http://creativecommons.org/licenses/by/4.0/

cc) (†) Open Access

\begin{abstract}
The civil servant exam has become the fiercest examination in China since 1994; more and more people take this examination. Among the candidates, college students have occupied the overwhelming majority who fanatically take part in the civil service exams and choose civil servants as their future career. This paper aims to discuss the reasons behind the civil servants' fever in China based on the comparison of Chinese and western values in four aspects: cultural, social, familial and personal. Finally, this paper makes an attempt to provide further suggestions to improve the unbalanced situation of the source allocation in China.
\end{abstract}

\section{Keywords}

\section{Chinese Value, Western Value, Civil Servants Fever}

\section{Introduction}

The establishment of China's system of public servants in 1987 and the formal implementation of merit system Examining and Employing officials work to make our country into the legal, standardized and to the gradual warming of civil service applicants. Following, "the tide of business", "the tide of civilian worker", "the tide of graduate school", and "the tide of national test" emerge. There is no doubt that now the university graduates looking for work who were born after 1980s and 1990s are the main examiners. The number of China's civil service applicants and examiners increased year by year since 2001; the number of civil service applicants was 32,904 , and the number surged to 62,268 in 2002 with an increase of 89\%, after then, the proportion of annual growth is in excess of $30 \%$. More and more college students choose civil servant as their future career and take part in civil servant examination. According to the latest data, there are about 1.41 millions of graduates taking the national civil servants recruitment in 2012. It hits the highest record in the history. The stable income, sound 
pension and enviable healthcare as well as the respectable social status of civil servants in China are the main temptations which can account for this social phenomenon.

In this paper, an analysis of civil servants rush in China will be made based on the comparison between Chinese and western values. Located in different continents, different countries have their unique cultures. The cultural differences have an influence on establishing people's world value. China and western countries share the world civilization. But they have diverse methods to present their cultural civilization. China is a traditional country with a long history of 5000 years. It is an agricultural nation. It focuses on collectivism. It emphasized on the relationship between man and man, man and nature, man and society, man and himself. Western countries pay more attention to themselves. They hold the idea that individuals are priority. For hundreds of years, westerners are fighting for their individual rights. Chinese and westerners will have diverse choices of their occupations. In recent years, there are a rising number of graduates who are enthusiastic about taking part in civil servants examination while their peers in the west may have a quite different choice. The comparison between the Chinese and western cultures may account for the current civil servants rush in China.

\section{A Comparison of Chinese and Western Values}

\subsection{Collectivism and Individualism}

Collectivism and individualism are the major dimension of cultural variability. From the cultural aspect, in collectivistic culture, the ingroup's goal takes precedence over individuals' goal. In contrast, individualism emphasizes more individuals' goal than ingroup's goal (Gudykunst \& Kim, 2008). Hofestede and Bond point out that in collectivistic culture "people belong to ingroups or collectivists which are supposed to look after them in exchange for loyalty", and in individualistic cultures "people are supposed to look after themselves and their family only" (Hofstede, 1984).

Chinese traditional value is based on collectivism, emphasizing the ingroup other than the individual. This conception originated from the production mode of small-scale agriculture economy. The product unit of this mode is based on household. People use simple tools to do farming work on dispersed lands. The time and space relationship provided for people is solid and static. The ability against nature is relatively low, which means people must rely on the group, like family. The severe existing environment leads to the harder self-existence for individual. This makes the ingroup more important. For most Chinese they lived in fixed family, unit and community. They are easily influenced by the whole group (Lei \& Yang, 2005). The cornerstone of Chinese culture is Confucianism. In the classic Chinese books, the Analects of Confucius, Confucius said, harmony is the most important. Harmony emphasizes on the coordinate relationship between man and man, man and nature, man and society, man and himself. It is a holism conception of the whole universe. In Confucianism, the concept of man is not the isolated individual nor an isolated entity, but a bigger entity including our family or our country. Hence, collectivism in China mainly refers to two aspects, of national and the family. That is to say, people should be loyal to their country and be filial to their parents. From this aspect, we can see that individual doesn't have independent value.

In western culture, individual is set in a highly important position. Selfishness is seen as the human nature. People should purse for their own happiness and personal profit. Egoism is the core of western culture. Although other people's profit and happiness in egoism should be considered, the theoretical basis of egoism still is "selfish is human nature". The starting line and end-result of people's action is pursuit for personal profit. Westerners view human as humanity, including the basis like happiness and desire. However, in Chinese culture human is equaled with moral integrity. Human as a moral exist, need to obey social morality. And the critical point of human and non-human based on morality. Morality is contradicted to personal desire, which indicates that obedience to morality has to repress individual natural and utilitarian desires.

In traditional Chinese culture, sons are seen as parents' support. They shoulder the responsibility to take care of their parents. But in the west, children are told to be independent at a very young age. They can't always depend on their parents. When they grow up they are set free to chase for what they like. Their parents don't rely on their children to care for them when they are old.

\subsection{Self-Ingroup Relationships in Collectivistic Culture}

In most writing self-ingroup relationship in collectivism is portrayed in one way. It's pointed out that there are 
three types of self-ingroup relationship that operate in collectivistic cultures: undifferentiated, relational and coexistence. In this paper, a further discussion about coexistence will be made.

The relational facet of collectivism is depicted by porous boundaries between ingroup members. It focuses on the relationship shared by ingroup members. This form requires people should feel and think what others are feeling and thinking (Markus \& Kitayama, 1991).

The coexistence facet of collectivism separates the public self and the private self. The public self is enmeshed with collectivist values (family loyalty) and coexist with private self, which maintains individualist values (personal striving). If individuals' goals are not compatible with the ingroup's goals, individuals are expected to sacrifice for the harmony of the group. Individuals are expected to behave on the basis of "what is expected of them" than "what they want to do" (Gudykunst \& Kim, 2008).

\subsection{Power Distance}

Hofstede and Bond define "power distance is the extent to which the less powerful members of institutions and organizations accept that power is distributed unequally” (Hofstede, 1984).

China is seen as a high power distance country. Individuals in high power distance cultures accept power as a part of society. Therefore, superiors consider their subordinates to be different from themselves. Members of high power distance cultures see power as a basic fact in society and stress coercive or referent power (Gudykunst \& Kim, 2008). In ancient China, subjects of a feudal ruler have to obey to their respectful monarch. At home, children must listen to their parents' opinion. The rules are especially harsh for women. They have to submit to their father as a young girl or their elder brother. After getting married, they must be obedient to their husband. Even when their husband die they have to listen to their son. From this perspective, we can sense the hierarchal in Chinese people's family life and in the society. In modern China, civil servants have the power to handle political stuff. They hold power to allocate the social resource. They are treated as a higher class. Because of the existing large power distance, civil servants are seen as a decent personage owning mass respect.

In western countries, people believe power should be used only when it is legitimate and power of officials is relatively small. In a company, subordinates have a limited dependence on boss. They will quite readily approach and contradict their bosses. The distance between civil servants and mass is relatively small. Civil servants service the public in their regulated authority. They are under strict supervision. They enjoy the national welfare like Chinese. But different from Chinese civil servants, they do not have privilege to reallocate the social resources, like transports, materials, etc. They need to protect the people's rights. In lawful society, the westerns' individual rights are respected. The mass have the relatively perfect laws to safeguard their rights. Civil servants must follow the lawful procedures. However, China is a social community ruled by man. Though laws are important in social life, human relationship still takes a highly position. If a man is in a high position, he holds the power to distribute social resources. He can yield profit by his power. And people who have close contract with the official can use the official's power to get what they want. In China having a family at a high position is much better than broad lawful knowledge. It is the root of abuse of authority. Meanwhile, it harms the social harmony and equality.

\section{An Analysis of the Current Civil Servants Fever}

\subsection{The Current Situation}

In recent years the number of college students is increasing. In 1999, China enlarged the recruitment of university students. From 2001 to 2008, the number of national graduates rises from 1.15 million to 5.59 million, at an annual rate of $20 \%$ (Tang, 2009). However, there is not enough suitable space for students in the job market when they graduate. More and more college students choose civil servant as their future career and take part in civil servant examination. According to the latest data, there are about 1.41 millions of graduates taking the national civil servants recruitment in 2012. It hits the highest record in the history. Different majors of students are set in this team, including students majoring in medicine, chemistry, machinery and philosophy, etc. They have their specialized knowledge and skills. But they give up what they have learned in the university and choose to be a public servant. Compared with Chinese colleges, the western undergraduates have more choices of future occupation. They have a relatively wider range of expected jobs, for instance, a pioneer of a corporation, an engineer, a doctor or a dancer. It seems that Chinese graduates are trapped in a circle only chasing for easy and 
comfortable life, but not colorful one. The huge number of candidates reflects the unbalanced source allocation in China.

\subsection{Cultural Reasons}

Civil servants rush is a special social event in China. Graduates who take the civil servants examination takes for a high percentage of the whole students. There is a tendency for college students to be public servants. This phenomenon is influenced by cultural background.

As a collectivistic nation, Chinese care about the group relationship and harmony. Working as a civil servant means the increasing opportunities to contract with different kinds of government functional department officers. If people have a harmonious relationship with these people, there may be a shortcut to solve the problem when people are facing with tough difficulties. China is a social community ruled by man. Laws are needed and also the human relations. This makes people dream of being a civil servant.

China is a high power distance country. Individuals accept power as a part of society. In China, civil servant is viewed as a decent job. People in this position are seen to be someone having the power to do things. This image is caused by the function and operation mechanism of Chinese civil servants' system. In China, civil servants are not only the serving for the people but also having privilege. They are treated as the center of national governing parts. They have the rights to govern and regulate. In the high power distance society, civil servants are seen prior to other walks of life.

\subsection{Social Reasons}

China is a society of official standard thought. Many people have the intention to be an official or a politician. Civil servants should have sacrifice spirits and do for the people. But many of Chinese candidates treat this job as a symbol of power and respectful social status. We can indicate that from the different situation of post position. Applicants are rushed to the better positions. On the contrary, some positions need quite a mount of candidates only to find no application.

There is another social reason. With the development of market economy, more jobs are provided and the risk to lose. Profit is seen as the priority of market economy. In every minute, employees are faced with the risk of unemployed due to the economy crisis or professional adjustment, etc. Compared with these jobs, civil servant is relatively stable and enjoys the welfare of nation without the risk of unemployment. Although civil servants' income is not that high, they have many preferences, for instance, the food allowance and household subsidy. In a national bureau canteen, the food is sold at 2 yuan. In Beijing, a civil servant can buy a house near the center of the city at a price of 6000 yuan a square meter in 2006. But in the market, the price is 20,000 yuan or much higher. According to the rapid development, the cost for civil servants is rather low.

In western countries, the individual goal is stressed. The power distance between people is relatively small. Subordinates have a limited dependence on the leader. They will quite readily approach their upper class. Civil servants in the west work as loyal employees. They have a pronounced division of labor. Strict laws and regulations forbid their abuse of authority.

\subsection{Familial Reasons}

China is a collectivistic country in which individual emphasizes more on the ingroup’s aim. Individuals are expected to behave on the basis of "what is expected of them" than "what they want to do" (Gudykunst \& Kim, 2008). Chinese people pay more attention on their family members. Confucianism is the basis of Chinese value, which promotes filial piety. There is a Chinese saying, children shouldn't go far from home when parents are alive. Similarly, children should listen to their parents' opinions. If they obey their parents' view, they will be labeled as impiety. For some parents, civil servant is an ideal profession. It is comfortable and stable. It has many advantages to under national protection. Civil servants have welfares and perfect social security system. They would like their children to have a try. Some of the candidates are forced to follow their parents' wish.

\subsection{Personal Reasons}

Most of the current college students are the only child in their family due to the Chinese planning policy. Different from other generations, this generation is grown under great intention and care. They adapt to enjoy leisure and 
comfort. They are self-centered and spoiled. Most of them are used to the protection from family members. When they leave university for the society, they intend to find less stressed job. Civil servants can have stable income and better social safeguard. What's more, it is a relatively steady occupation. All these catch graduate students to be a civil servant. Compared with civil servants, other jobs need more energy and effort to get steady.

\section{Conclusion}

In recent years the number of people taking civil servants examination is rising year by year. It has hit the highest historical record. 1.41 million applicants take part in the national civil service exam of 2012. This indicates that more and more educated graduate students choose civil servants as their future career.

The division of college programs is becoming meticulous. But there is not enough work space for colleges in the society. This shows the imbalance of social sources. Higher educated students are fight to be a civil servant but there is wider space outside the world for them to realize their dreams. There is a need of civilized talents to manage nation. However, talents are also needed in corporations and scientific institutions. The unbalanced occupation situation has an impact on the long-term social development.

Personal departments and universities should put more energy in job guidance. It is important to provide guidance and set a future career for students. At the same time, college students should set up a correct occupation outlook and change their traditional view of employment. The change of civil servants is also needed. Civil servants are the public servants and should serve for people. Dedication, courage, ability of political discernment, analysis and comprehensive coordinate are all needed for a qualified civil servant.

The civil servants rush indicates the shortage of civil servants management mechanism, for example, supervision system. A critical civil servant testing and evaluating system is needed urgently. It should represent the conception of scientific development. Guided by individual ability and achievements, a testing and evaluation system should serve for people and is useful in different regions.

Social security system needs perfection. The current social security system is marrow and incomplete. It is a dual social system between cities and villages. There is a gap among different regions and industries. Quite a number of township labors and farmers are excluded out of the social security system (Tang, 2009). From the civil servants rush, we can see that the incomplete social security system has influenced the rational allocation of social resources in employment environment and human resources. A broad social secure covered all kinds of social groups will safeguard people's equal social rights. In this way, the employment situation develops. Furthermore, social harmony and stability are maintained. Civil servants are not the only choice for graduate students. They need to make a scientific plan for their career based on their advantages and disadvantages and current situation.

\section{References}

Gudykunst, W. B., \& Kim, Y. Y. (2008). Communication with Strangers: An Approach to International Communication. Shanghai: Shanghai Foreign Language Education Press.

Hofstede, G. (1991). Cultures and Organizations: Software of the Mind. London: McGraw-Hill.

Lei, J. M., \& Yang, W. Q. (2005). The Influence of the Chinese-Western Values Conflicts on the Character Molding of College Students. Hubei Social Sciences, No. 5, 150-153.

Markus, H., \& Kitayama, S. (1991) Culture and the Self: Implications for Cognition, Emotion, and Motivation. Psychological Review, 98, 224-253. http://dx.doi.org/10.1037/0033-295X.98.2.224

Tang, J. (2009). On the Civil Servant Rush. China High-Tech Industry, No. 5, 181 
Scientific Research Publishing (SCIRP) is one of the largest Open Access journal publishers. It is currently publishing more than 200 open access, online, peer-reviewed journals covering a wide range of academic disciplines. SCIRP serves the worldwide academic communities and contributes to the progress and application of science with its publication.

Other selected journals from SCIRP are listed as below. Submit your manuscript to us via either submit@scirp.org or Online Submission Portal.
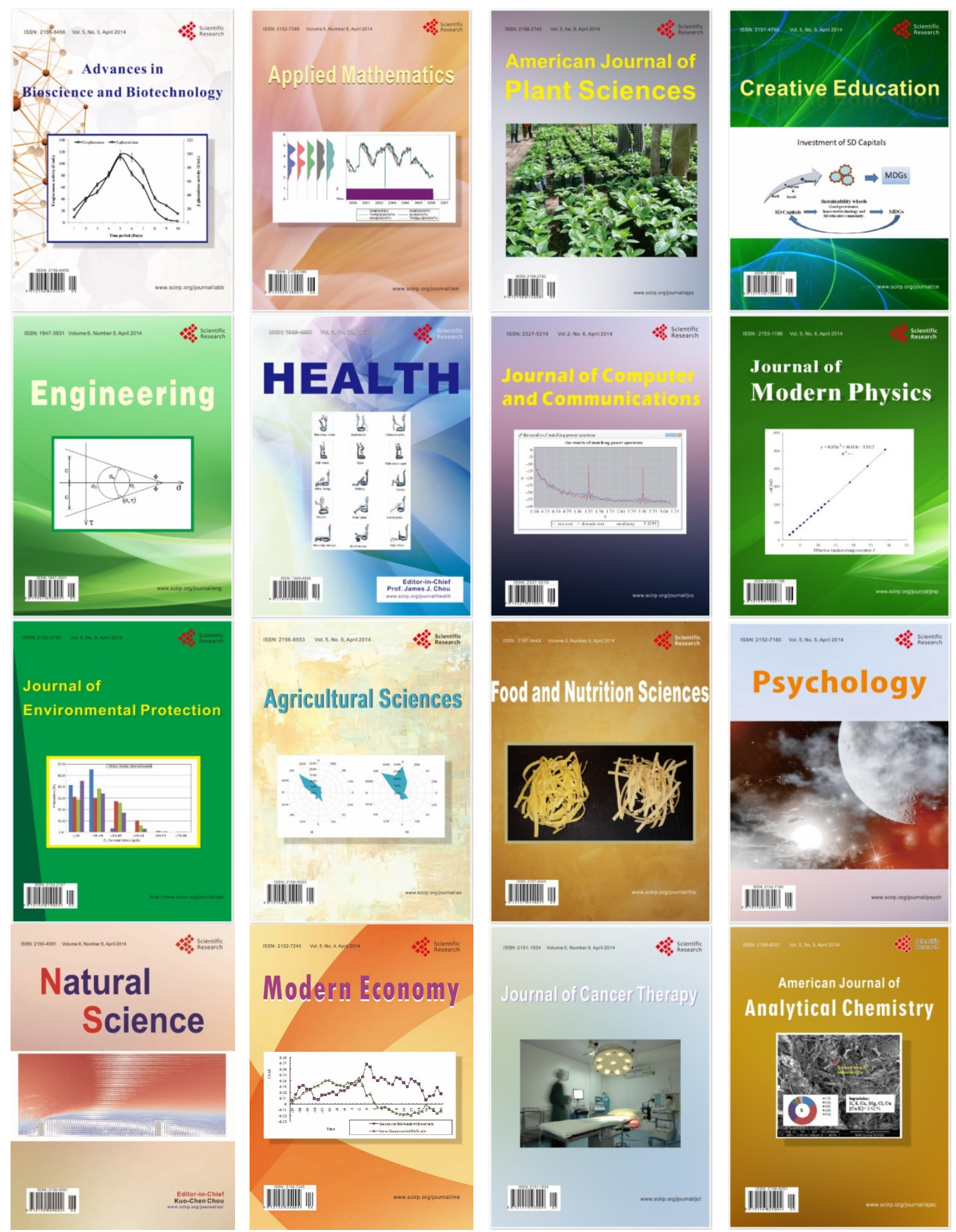